\title{
AN ANALYSIS OF FACTORS INFLUENCING EMPLOYEE JOB SATISFACTION IN A PUBLIC SECTOR
}

\author{
Nemanja Lekić, Jelena Vapa-Tankosić, \\ Jasmina Rajaković-Mijailović, Snežana Lekić
}

\section{Introduction}

Job satisfaction is one of the most researched of employee attitudes (Alotaibi, 2001; Parnell \& Crandall, 2003), and is considered to be essential for job performance. On the one hand, job satisfaction may have a direct influence on employees, leading them to identify their individual goals with those of their organization, and on the other, it can lead to more efficient realization of established organizational goals. There are numerous reasons for companies to regularly conduct job satisfaction surveys: getting to know the current level of job satisfaction, better management of employee expectations, building an effective business culture or finding new ways to improve business results, and attract quality candidates. The results of such surveys may be used to increase their commitment to the organization. A positive climate among the employees encourages innovation, strengthens initiatives and enables successful execution of tasks. This means that each organization needs to build a sense of belonging and respect among all employees. Any organization can provide a context within which high levels of motivation can be achieved by providing incentives and rewards, a satisfactory working environment and opportunities for learning and growth. Managers should play a major role in motivating employees to give their best, using the motivation tools provided by the organization (Armstrong \& Taylor, 2014). Companies are faced with growing competition and demand for constant flexibility and business improvement in the current global business environment. In such a business environment, a company must increasingly respect the axiom in which technological and business capital depend on human capital, that is, on working abilities, education, relevant experience and career development. Also, the level of education of the employees is in direct correlation with the possibility of assessing the factors that determine employee job satisfaction and good business results (Lekić, Bogetić, \& VidasBubanja, 2014, p. 29).

The complexity of the current business environment, where companies must keep track of large amounts of data, and a multiplicity of factors from the external environment economic, political, and social - demands that managers understand changes, focus on them, and motivate all employees to respond effectively (Lekić \& Rajaković-Mijailović, 2017 , p. 236). Job satisfaction is an important dimension for the well-being of employees, but it is also an indication of organizational success (Culbertson, 2009; Korunka et al., 2003). The basic competitive advantage of every company is found in its employees. This implies that the employees are satisfied with the job they perform and that their positions correspond to their knowledge, abilities and capabilities. Job satisfaction encompasses the overall employees' attitude towards work, nature of the work itself, income and benefits, personal status in the organization, interpersonal relations, and communication with superiors, opportunities for improvement and promotion and exercising all rights from employment.

Achieving an increase in job satisfaction in public enterprises implies permanent improvement of human resources activities and new public sector management. The importance of the public sector is reflected in the fact that it enables the materialization and realization of public interests important for the society as a whole. Research shows that differences in job satisfaction between the private and public sectors can also be the result of different sources of motivation, as public sector employees are less extrinsically motivated (monetary rewards) and more 
motivated by working in the supportive working environment. However, public sector employees were less motivated by intrinsic factors, such as responsibility and self-development (Buelens \& Van den Broeck, 2007).

Findings of Tschirhart et al. (2008) reveal a positive relationship between a preference for helping others with a desire for work in the the public sector ("public service motivation PSM"), but do not show a significant relation between the importance of having a high salary in relation to desire for work in public sector (as it has been positively related in the business sector). Lewis and Frank (2002) were unable to establish high levels of PSM as a predictor for public sector employment. Another strand of research argues that PSM does not automatically increase employee attraction to or satisfaction with public employment, while higher salaries increase the likelihood of accepting a job, regardless of their PSM levels (Christensen \& Wright, 2011).

Job security is emphasized to be a very important factor of government jobs, encompassing the opportunity to be useful to society while working in the public service. Research on the level of earnings in transition countries shows that wages for the same job in the public sector were significantly lower than in the private sector at the beginning of the transition, but as transition reforms have progressed the public wages increased to reflect a convergence between the trends of developed and transition countries (Lausev, 2014). The subject of this research is an analysis of job satisfaction in public sector in Belgrade region in two independent time periods. After the introductory section, the authors present the theoretical and the methodological framework, which is followed by the research results, discussion and conclusion.

\section{Theoretical Framework for Research on Job Satisfaction}

One of the first theoretical approaches to job satisfaction is to be found in the Locke value theory (Locke, 1976; Greenberg \& Baron, 1999, p. 161-162). According to this theory, job satisfaction is present to the extent that employees are satisfied with the outcome of the work itself. Locke defined job satisfaction as a positive emotional feeling, a result of the individual's evaluation of his job or his experience of work comparing between what he expects from his job and what he actually gets from it. Locke (1969, p. 316) also identifies three factors in action in any job appraisal process: perception of a facet of the job, a value system, and an evaluation of the relationship between perception and value system. One employee may be strongly influenced by the physical aspects of the job whilst another may be influenced by the challenge and variation inherent in the job (Locke, 1976). Baron and Greenberg (2003, p. 156-157) argue that although Locke's theory has not been extensively researched, the degree of emphasis placed on values suggests that job satisfaction may arise from such factors.

The satisfaction is also influenced by expectations (importance) and satisfaction with individual dimensions of a job. The value theory is important because it puts emphasis on certain job aspects that need to be changed in order to make employees more satisfied. It emphasizes that these aspects do not have to be the same for all people, but can be any aspect of a job where employees notice serious disaccord. All aspects of a certain job, good and bad, positive or negative are likely to contribute to the development of feelings of satisfaction or dissatisfaction (Riggo, 2013).

Job satisfaction proves to be a complex and multidisciplinary concept arising from a combination of psychological, physiological and environmental circumstances and most authors associate job satisfaction with attitudes and emotions related to the job. Job satisfaction can be defined as a positive feeling about one's job resulting from an evaluation of its characteristics (Robbins \& Judge, 2009, p. 79).

It encompasses the "cognitive, affective, and evaluative reactions of an individual to his job" (Greenberg \& Baron, 1999, p. 157). In the most general sense, job satisfaction can be defined as "the positive or negative attitude that people have about their business" (Skaalvik \& Skaalvik, 2015 , p. 181), a derived inner attitude from the realization of wishes and needs from career experience (Hoekstra, 2014) and how people feel about their jobs (Kitchel et al., 2012). Job satisfaction is a complex attitude that includes three components: cognitive (assumptions and beliefs about the job), affective (feelings for the job), and behavioral (job evaluation). Satisfaction with work is influenced by numerous factors that can be divided into individual and organizational categories. Organizational 
factors play an important role in job satisfaction (Sageer, Rafat, \& Agarwal, 2012, p. 33), stemming from the fact that employees spend most of their time in the organization where they work. Job satisfaction can be improved by managing organizational variables (through organizational development, reward systems, promotion and career development, general job satisfaction, job security, work environment and conditions, mentoring relationships, teamwork, management style, etc.). In addition to organizational, individual characteristics are also important (interconnection of personal interests and job, work experience and years of service, gender, education, position and status, total satisfaction, etc.).

Three factors impact on the psychological state of employees, affecting their reactions to the characteristics of their jobs: the significance of the work, the experienced responsibility at work and knowledge of the results. Namely, the employee must perceive their job as something valuable and important in their own value system, they must believe that they are responsible for results in the workplace and they must be able to determine that the results of their work are followed by a transparent reward system. If effective incentive plans and proper training are given to employees then their performance can be increased and they do become more satisfied with their jobs (Tahir, Yusoff, Azam, Khan, \& Kaleem, 2012).

There are numerous studies showing that emotions and affectivity are a significant factor in job satisfaction. The theoretical basis is found in the Big Five model. In recent years, a broad though by no means universal consensus has developed that the structure of the personality can be encompassed by the five superordinate Big Five dimensions of Neuroticism, Extraversion, Openness to Experience, Agreeableness and Conscientiousness (John, 1990; John \& Robins, 1993; McCrae \& Costa, 1990; McCrae \& John, 1992; Judge, Heller, \& Mount, 2002). It is also confirmed that satisfaction with one's job may influence various aspects of work such as efficiency, productivity, absenteeism, turnover rates, and intention to quit and also an employee's total wellbeing (Baron, 1986; Maghradi, 1999; Robbins \& Coulter, 2005).

In order for an organization to be successful, it must "recruit talented people at all levels, who possess the right combination of skills and abilities that implies true values and attitudes"
(Dess, Lumpkin, \& Eisner, 2007, p. 127). Such skills and attitudes must be developed and strengthened constantly, with each employee adequately motivated and his efforts focused on the goals and tasks of the organization. The value of the organization does not stem from its tangible assets, but is based on knowledge, skills and intellectual property, all of which rests on people. Human capital is the basis of intellectual capital made up of human, structural and relational capital (Lim \& Dallimore, 2004; Choong, 2009).

In the realization of a business strategy, job satisfaction plays an important role. If the employee is satisfied with his/her work he will be motivated to give his maximum in achieving organizational goals, which will directly affect the performance of the organization (De Menezes, 2011, p. 309). Managers have the task to take all necessary measures to ensure that employees are motivated and committed to work. Employees with a high level of satisfaction are less absent from work, they are less likely to go to another organization, are more productive, more loyal to their organization, and more satisfied with their work (Chahal et al., 2013, p. 12). All this leads to the need to identify the basic parameters of job satisfaction, in order to contribute to the increase in total job satisfaction. Only a satisfied employee will influence the creation of a positive corporate identity, image and reputation of their organization, since they identify their individual goals with the goals of the organization (Pavković \& Lekić, 2015).

The Job Descriptive Index that has been designed and copyrighted by Smith, Kendall and Hulin (1969) encompasses a 72-item adjective checklist questionnaire for measuring job satisfaction, as they considered job satisfaction to becomprised of five dimensions: pay, promotions, coworkers, supervision and work. The index has been widely used in scientific research (Yeager, 1981). The factor structure of job satisfaction 30-question multiplechoice format, based on the copyrighted Job Descriptive Index (Smith, Kendall, \& Hulin, 1969), was utilizied to assess job satisfaction of public accountants (Gregson, 1987). His findings have pointed out that male certified public accountants were more satisfied with the promotion dimension of job satisfaction than female, that the pay dimension of job satisfaction was positively associated to tenure with firm and that the measure of job 
satisfaction was highly negatively associated with intent to turnover (Gregson, 1990, p. 792). The results of the survey of the members of the EU Public Administration Network (EUPAN) of representatives of public administration institutions of all EU members, the European Commission as well as of Norway, Switzerland and Serbia (members with observer status) on performance appraisal of civil servants working in central public administration point out that many countries have reformed the performance appraisal system in order to make it more effective. Since 2007, increasing professionalisation, standardisation of performance appraisals across departments and performance appraisal process have occurred (Staroňová, 2017, p. 62). A survey of 365 respondents among the top level of public managers (in Copenhagen, Rotterdam and Barcelona municipalities) on important leadership qualities for public innovation point out that the collaborative element is seen as important in all three cities, while the leadership style for innovation is mostly perceived as a mix of a transformational leadership style that emphasizes visionary leadership (Ricard, Klijn, Lewis, \& Ysa, 2017, p. 151).

The basic function and task of the existence of the public sector is the development of the national economy and the private sector. Working in the public sector increases total job satisfaction (Heywood et al., 2002; Ghinetti, 2007). A meta-analysis of the review of literature between job satisfaction and 43 correlates in public administration finds that job satisfaction is strongly positively correlated with mission valence, commitment, person-job fit, inclusion, trust, intrinsic motivation, justice, autonomy, organizational performance, and personorganization fit (Cantarelli et al., 2016). Another findings of meta-regression analysis indicate that the strength of the link between public service motivation and job satisfaction varies considerably depending on the dimension being examined, whereas commitment to the public interest and self-sacrifice contribute to job satisfaction but the aggregated effect of attraction to policy making and compassion dimensions are weakly or not significantly related to job satisfaction (Homberg, McCarthy, \& Tabvuma, 2015, p. 717). Results of a study of local government departments of the UAE indicated that public employees are highly satisfied with supervision and coworkers, but they have low satisfaction with pay and promotion facets of the job. However, the satisfaction with pay, promotion, coworkers, and security directly and positively influence affective commitment (Yousef, 2017).

There is no general model of employee satisfaction measurement in public sector in Serbia as it has not been fully integrated into the human resource management. Each public enterprise should create it in accordance with their strategy and business objectives. Human resources in the public sector are the most important resource of the organization, because they have a decisive influence on the achievement of the set goals and performance in the work. They cover the total intellectual, psychological, physical and social energy that can be developed and used to achieve the goals of the organization (Pržulj, 2011, p. 12).

\section{Methodological Framework of Research}

The aim of the research is to identify whether satisfaction with salary, cooperation with closest associates, possibility of promotion, remuneration policy, cooperation and good relationships with superiors and nature of the job have a statistically significant effect on total job satisfaction.

The following hypotheses have been defined:

H1: Satisfaction with salary is directly and positively associated with total job satisfaction.

H2: Satisfaction with cooperation with closest associates is directly and positively associated with total job satisfaction.

H3: Satisfaction with possibility of promotion is directly and positively associated with total job satisfaction.

H4: Satisfaction with remuneration policy is directly and positively associated with job satisfaction.

H5: Satisfaction with cooperation and good relationships with superiors is directly and positively associated with total job satisfaction.

H6: Satisfaction with nature of the job is directly and positively associated with total job satisfaction.

The graphical representation of the model is shown in Fig. 1. The data analysis has been performed by correlation, covariance, regression analysis, t-statistics and F-statistics. Data processing was performed using 


\section{Fig. 1: Graphical representation of the research model}

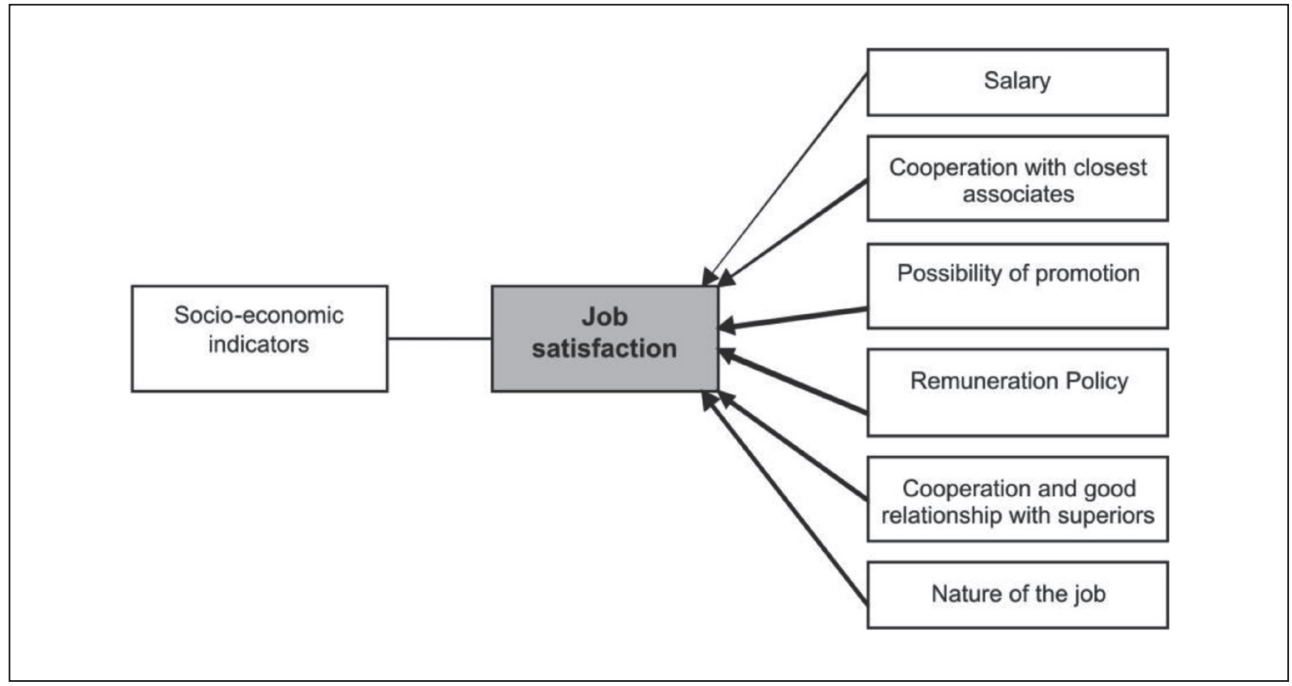

Source: own research

the statistical software package SPSS 19.0. The level of significance was set at $p=0.05$.

The research was carried out in two independent monitored time periods. The total number of employees at vaious departments investigated in 2010 and in 2017 in public enterprises was 1,050 . In 2010, a sample of 500 employees was drawn and 500 printed questionnaires were distributed in a two month period, while in 2017 a sample of 550 employees was drawn and 550 printed questionnaires were distributed in a three month period. Of the distributed questionnaires, 492 were returned usable (98\% response rate) in 2010 (Lekić, 2010). In 2017, 508 distributed questionnaires were returned usable (92\%). The anonymous survey was conducted on a sample of respondents on lower positions while in the second period, which was treated as a control period, 508 lower positions respondents were surveyed from the same public enterprises. In both cases, the survey included a sample of communication, logistic and infrastructure public enterprises and a public higher education institution in the Belgrade region.

The first part of the survey refers to socioeconomic indicators (gender, age, year of service and qualifications). In the second part of the survey, job satisfaction was measured, using an adjusted job satisfaction questionnaire (Gregson, 1987, p. 747-750). These five dimensions, prevalently cognitively based with some affective influences also present in some dimensions (Brief \& Roberson, 1989), of the Job Descriptive Index (work, pay, promotions, supervision, and coworkers) have been selected on the basis on this study performed on certified public accountants. The considered dimensions of the Job Descriptive Index are salary (how satisfied the employee is with the level of employee salaries comparable to other salaries in public sector), cooperation with closest associates (how satisfied the employee is with his coworkers), possibility of promotion (how satisfied the employee is with the opportunities for promotions), cooperation and good relationships with superiors (how satisfied the employee is with the supervisor's behaviour), and nature of the job (e.g. job content, how satisfied the employee is with his/her job in general, type of work that he/ she does). The sixth dimension (remuneration policy - how satisfied the employee is with the policy that encourages, motivates and retains its' employees) has been included in the research as an important parameter 
of public sector remuneration and benefits system management that promotes positive employee outcomes. Public employees are usually expected to be also guided by the public interest and public service motivation (not only by salary preferences) and their salaries are often lower than those in the private sector.

Measurement of job satisfaction was carried out using the model of measuring the total satisfaction of employees in the enterprise based on six variables: $c_{1}$ - satisfaction with salaries, $C_{2}-$ satisfaction with cooperation with closest associates, $\mathrm{C}_{3}$ - satisfaction with the possibility of promotion on the hierarchical level, $\mathrm{c}_{4}$ - satisfaction with the remuneration policy, $c_{5}$ - satisfaction with cooperation and relations with superiors, and $\mathrm{C}_{6}-$ satisfaction with the nature of the job.

In second part of the study, we have perfomed variance and regression analysis (Christensen, 1996) to identify whether the identified variables have a significant impact on employee job satisfaction. The five-point Likert scale has been used with possible answers: 1 - extremely dissatisfied, 2 - dissatisfied, 3 - satisfied, 4 - quite satisfied, 5 - extremely satisfied.

The total job satisfaction (TJS) was calculated on the basis of the six different variables $\left(c_{\mathrm{ji}}\right)$, therefore the satisfaction of the individual employee has been obtained as:

$$
T J S_{i}=\frac{\left(c_{1 i}+c_{2 i}+c_{3 i}+c_{4 i}+c_{5 i}+c_{6 i}\right)}{6}
$$

where: $\mathrm{i}=1, \ldots, \mathrm{n}$; while $\mathrm{n}$ represents the total number of employees.

This coefficient shows the average value of total job satisfaction on the basis of the scores of six variables. For the analysis of total job satisfaction at the level of the enterprise as a whole, the total job satisfaction coefficient (TJS) is calculated as:

$$
T J S=\frac{\left(c_{1}+c_{2}+c_{3}+c_{4}+c_{5}+c_{6}\right)}{6}
$$

whereas:

$$
c_{j}=\frac{\sum_{i=1}^{n} c_{i j}}{n},(j=1, \ldots, 6)
$$

\section{Research Results}

The structure of the sample by gender, age, level of education and the number of years spent in the organization is shown in Tab. 1. The results of descriptive statistics are shown in Tab. 2.

Descriptive statistics show that $57.3 \%$ of respondents to the survey conducted in 2017 were female and $42.7 \%$ male. The average age of the respondents, is 40.70 years and regarding education, $38.4 \%$ have a university degree. On average the respondents had spent 12.6 years in his/her organization. Compared with the results from 2010, the results is similiar as female respondents still represent a majority. The average age of the respondents in this period was 39.42 years, and $39.4 \%$ had a university degree having spent on average, 13.83 years in the enterprise. Analyzing the obtained results, there were no statistically significant differences between the respondents in 2017 compared to 2010, according to gender structure and age.

In relation to vocational training, in the year 2017, there was an increase in the number of educated persons and in the number of persons with academic titles. According to the number of years spent in the organization, there was a slight decline in a number of years of work experience of respondents in 2017. The obtained results can be considered relevant and adequate for the application of comparative analysis.

The results obtained in Tab. 2 indicate the following. The average score of salary satisfaction $\left(c_{1}\right)$ in 2010 is 2.82 (Std. Dev. 1.08), and in 2017 is 3.28 (Std. Dev. 1.12). The Paired Samples Test examined the significance of the difference in the salary satisfaction of the respondents in the analyzed period. By comparing the score of salary satisfaction we can conclude that there is a statistically significant difference between the salary satisfaction scores. We have to bear in mind that the respondents' salaries were reduced in recent years because of crisis measures by decision of the government. Given the higher number of unemployed in 2017 due to the effects of the economic crisis, the employees are satisfied if their salaries, albeit reduced by government mesures, are regular. Due to the increasing unemployment and uncertainty in the country in transition, the public sector employees are more satisfied with salaries in 2017 because they also feel that their job gives them security 
Tab. 1: Structure of the sample according to socio-economic indicators

\begin{tabular}{|c|c|c|c|c|c|}
\hline & \multicolumn{2}{|c|}{2010} & \multicolumn{2}{|c|}{2017} \\
\hline & & Frequency & Percentage & Frequency & Percentage \\
\hline \multirow[t]{3}{*}{ Sex } & Male & 208 & 42.3 & 217 & 42.7 \\
\hline & Female & 284 & 57.7 & 291 & 57.3 \\
\hline & Total & 492 & 100.0 & 508 & 100.0 \\
\hline \multirow[t]{5}{*}{ Age group } & Up to 35 & 194 & 39.4 & 189 & 37.2 \\
\hline & $35-55$ & 250 & 50.8 & 258 & 50.8 \\
\hline & Over 55 & 48 & 9.8 & 61 & 12.0 \\
\hline & Total & 492 & 100.0 & 508 & 100.0 \\
\hline & & \multicolumn{2}{|c|}{$\begin{array}{l}\text { Average value: } 39.42 \\
\text { Std. Dev }=11.22 \\
\text { Coeff. Var }=28.46 \%\end{array}$} & \multicolumn{2}{|c|}{$\begin{array}{l}\text { Average value: } 40.70 \\
\text { Std. Dev }=6.08 \\
\text { Coeff. Var }=14.95 \%\end{array}$} \\
\hline \multirow[t]{5}{*}{ Education* } & D & 172 & 35.0 & 182 & 35.8 \\
\hline & C & 95 & 19.3 & 92 & 18.1 \\
\hline & B & 194 & 39.4 & 195 & 38.4 \\
\hline & A & 31 & 6.3 & 39 & 7.7 \\
\hline & Total & 492 & 100.0 & 508 & 100.0 \\
\hline \multirow{6}{*}{$\begin{array}{l}\text { The number } \\
\text { of years spent } \\
\text { in the organization }\end{array}$} & Less than 5 & 119 & 24.2 & 117 & 23.0 \\
\hline & 6-15 & 219 & 44.5 & 221 & 43.5 \\
\hline & $16-20$ & 55 & 11.2 & 63 & 12.4 \\
\hline & Over 20 & 99 & 20.1 & 107 & 21.1 \\
\hline & \multirow[t]{2}{*}{ Total } & 492 & 100.0 & 508 & 100.0 \\
\hline & & \multicolumn{2}{|c|}{$\begin{array}{l}\text { Average value: } 13.83 \\
\text { Std. Dev }=10.40 \\
\text { Coeff. Var }=75.17\end{array}$} & \multicolumn{2}{|c|}{$\begin{array}{l}\text { Average value: } 12.6 \\
\text { Std. } . \text { Dev }=5.49 \\
\text { Coeff.Var }=45.22 \%\end{array}$} \\
\hline
\end{tabular}

Source: own research

Note: * A. post-graduate qualification, B. college diploma, C. higher educational diploma, D. high school diploma.

from being easily fired or laid off, as opposed to the private sector employees.

In 2010, the average score of satisfaction with cooperation with closest associates $\left(\mathrm{C}_{2}\right)$ was 3.32 (Std. Dev. 0.95), while in 2017 this average estimate was 3.25 (Std. Dev. 0.88). The Paired Samples Test examined the significance of the difference in the satisfaction of the respondents in the analyzed period. By comparing the satisfaction scores of the cooperation with the closest associates, the differences are on average equal to 0 , therefore we can conclude that there is a statistically small difference between the satisfaction with cooperation with closest associates score. Compared to 2010, there was a decrease in the satisfaction of cooperation with the closest associates, which speaks of lack of cooperation with associates, which points to increased atmosphere of individual work and individual responsibility.

The average score for the possibility of progression on the hierarchical scale $\left(\mathrm{C}_{3}\right)$ in 2010 is 2.82 (Std. Dev. 1.03), and in 2017, 3.25 (Std. Dev. 1.15). Using the Paired Samples Test we examined the significance of the difference. By comparing the satisfaction scores of the possibility of promotion on the hierarchical level we conclude that there is a statistically significant difference between the score of satisfaction with the possibility of promotion on the hierarchical level. These results can also point to the conclusion that the organizational climate no longer applies the principle of seniority in hierarchical progression. If we 
Tab. 2: Descriptive indicators for job satisfaction parameters

\begin{tabular}{|c|c|c|c|c|c|c|c|c|c|c|c|c|c|}
\hline & & $\mathbf{N}$ & 1 & 2 & 3 & 4 & 5 & Min & Max & Mean & Std.Dev. & Varian. & $\begin{array}{c}\text { Coeff. } \\
\text { Var. }\end{array}$ \\
\hline \multirow[t]{2}{*}{$c_{1}$} & 2010 & 492 & 55 & 134 & 182 & 85 & 36 & 1 & 5 & 2.82 & 1.075 & 1.155 & 38.08 \\
\hline & 2017 & 508 & 26 & 91 & 203 & 92 & 96 & 1 & 5 & 3.28 & 1.116 & 1.246 & 34.02 \\
\hline \multirow[t]{2}{*}{$\mathrm{C}_{2}$} & 2010 & 492 & 13 & 69 & 214 & 138 & 58 & 1 & 5 & 3.32 & 0.946 & 0.895 & 28.47 \\
\hline & 2017 & 508 & 9 & 85 & 219 & 159 & 36 & 1 & 5 & 3.25 & 0.879 & 0.773 & 27.04 \\
\hline \multirow[t]{2}{*}{$\mathrm{C}_{3}$} & 2010 & 492 & 46 & 138 & 201 & 72 & 35 & 1 & 5 & 2.82 & 1.027 & 1.055 & 36.42 \\
\hline & 2017 & 508 & 26 & 110 & 180 & 93 & 99 & 1 & 5 & 3.25 & 1.150 & 1.322 & 35.35 \\
\hline \multirow[t]{2}{*}{$\mathrm{C}_{4}$} & 2010 & 492 & 79 & 139 & 178 & 64 & 32 & 1 & 5 & 2.66 & 1.095 & 1.199 & 41.23 \\
\hline & 2017 & 508 & 31 & 147 & 161 & 144 & 25 & 1 & 5 & 2.97 & 1.007 & 1.015 & 33.91 \\
\hline \multirow[t]{2}{*}{$C_{5}$} & 2010 & 492 & 15 & 88 & 205 & 114 & 70 & 1 & 5 & 3.28 & 1.014 & 1.028 & 30.93 \\
\hline & 2017 & 508 & 33 & 120 & 172 & 76 & 107 & 1 & 5 & 3.20 & 1.204 & 1.449 & 37.50 \\
\hline \multirow[t]{2}{*}{$\mathrm{C}_{6}$} & 2010 & 492 & 15 & 82 & 232 & 118 & 45 & 1 & 5 & 3.19 & 0.926 & 0.857 & 28.99 \\
\hline & 2017 & 508 & 28 & 92 & 136 & 117 & 135 & 1 & 5 & 3.47 & 1.220 & 1.476 & 35.16 \\
\hline
\end{tabular}

Source: own research

regard the satisfaction with the possibility of promotion as a score based on his/her individual ability, we conclude that the organizational climate stimulates the individual competence of employees taking into account the results achieved. If, however, there is a possibility of advancing on a hierarchical scale according to non-transparent criteria then this result can be interpreted as unethical management of human resources. If we compare this result with a lesser degree of satisfaction with the closest associates, the ultimate conclusion is that less attention is paid to team work, while individual work and competitive spirit are encouraged, and promotion on the hierarchical scale is achieved based on the individual ability of employees.

The average score of satisfaction with the remuneration policy $\left(\mathrm{C}_{4}\right)$ in 2010 was 2.66 (Std. Dev. 1.10), and in 2017, 2.97 (Std. Dev. 1.01). By comparing the scores of satisfaction with the remuneration policy we conclude that there is a statistically significant difference between the satisfaction scores for the remuneration policy. The increased value speaks in favor of the fact that employers monitor, recognize and adequately stimulate good results.

In 2010, the average score of satisfaction with cooperation and relations with superiors $\left(\mathrm{C}_{5}\right)$ was 3.28 (Std. Dev. 1.01), while in 2017, 3.20 (Std. Dev. 1.20). By comparing the scores of satisfaction with cooperation and relationships with superiors we conclude that there is a statistically small difference between the satisfaction scores of cooperation and relations with superiors. The decline in the average score may be the result of a lack of teamwork, the formalization of working relationships through a clearly hierarchical structure in which the former practice of informal communication gives way to formal relationships aimed at pure task execution.

The satisfaction with the nature of the job $\left(\mathrm{c}_{6}\right)$ in 2010 obtained an average score of 3.19 (Std. Dev. 0.93), and in 2017, this score is 3.47 (Std. Dev. 1.22). By comparing scores of satisfaction of the nature of the job we conclude that there is a statistically significant difference between the two iterations of the test. The nature of the job is a determining factor in the establishment of work relations. However, given that the nature of the job in the public sector where the survey was conducted has not substantially changed, this satisfaction actually represents satisfaction with his/her public service employment.

Tab. 3 shows total job satisfaction (TJS) as the average score. The average job satisfaction score was 3.02 in 2010, and by 2017 it had increased to 3.24 . This increase can be explained by increase of satisfaction with the salaries, the possibility of promotion, the remuneration policy and the nature of the job, according to the foregoing. 
Tab. 3: Total job satisfaction (TJS)

\begin{tabular}{c|c|c|c|c|c|c|c|c} 
& $\mathbf{N}$ & $\mathbf{C}_{\mathbf{1}}$ & $\mathbf{c}_{\mathbf{2}}$ & $\mathbf{C}_{\mathbf{3}}$ & $\mathbf{C}_{\mathbf{4}}$ & $\mathbf{c}_{\mathbf{5}}$ & $\mathbf{c}_{\mathbf{6}}$ & $\mathbf{T J S}$ \\
\hline 2010 & 492 & 2.82 & 3.32 & 2.82 & 2.66 & 3.28 & 3.19 & 3.02 \\
\hline 2017 & 508 & 3.28 & 3.25 & 3.25 & 2.97 & 3.20 & 3.47 & 3.24 \\
\hline
\end{tabular}

Source: own research

\section{Tab. 4: Matrix of covariants scores of different variables of total job satisfaction for the entire sample in 2017 and 2010}

\begin{tabular}{|c|c|c|c|c|c|c|c|c|c|c|c|c|}
\hline & \multicolumn{6}{|c|}{$2017(N=508)$} & \multicolumn{6}{|c|}{$2010(N=492)$} \\
\hline & $\mathrm{c}_{1}$ & $\mathrm{c}_{2}$ & $\mathrm{c}_{3}$ & $\mathrm{c}_{4}$ & $\mathrm{C}_{5}$ & $\mathrm{c}_{6}$ & $\mathrm{C}_{1}$ & $\mathrm{C}_{2}$ & $\mathrm{C}_{3}$ & $\mathrm{C}_{4}$ & $\mathrm{C}_{5}$ & $\mathrm{C}_{6}$ \\
\hline $\mathrm{C}_{1}$ & 1.244 & & & & & & 1.154 & & & & & \\
\hline $\mathrm{C}_{2}$ & 0.812 & 0.771 & & & & & 0.490 & 0.894 & & & & \\
\hline $\mathrm{C}_{3}$ & 1.103 & 0.767 & 1.319 & & & & 0.692 & 0.503 & 1.053 & & & \\
\hline $\mathrm{C}_{4}$ & 0.926 & 0.706 & 0.905 & 1.013 & & & 0.777 & 0.509 & 0.839 & 1.197 & & \\
\hline $\mathrm{C}_{5}$ & 1.172 & 0.850 & 1.080 & 1.034 & 1.446 & & 0.565 & 0.592 & 0.588 & 0.658 & 1.025 & \\
\hline $\mathrm{C}_{6}$ & 1.072 & 0.820 & 0.894 & 0.929 & 1.274 & 1.474 & 0.518 & 0.496 & 0.553 & 0.565 & 0.607 & 0.856 \\
\hline
\end{tabular}

Source: own research

\begin{tabular}{|c|c|c|c|c|c|c|c|c|c|c|c|c|c|c|}
\hline \multicolumn{2}{|c|}{ Tab. 5: } & \multicolumn{13}{|c|}{$\begin{array}{l}\text { Matrix coefficients of Pearson correlation for the entire sample in } 2017 \\
\text { and } 2010\end{array}$} \\
\hline & \multicolumn{7}{|c|}{$2017(N=508)$} & \multicolumn{7}{|c|}{$2010(N=492)$} \\
\hline & $c_{1}$ & $c_{2}$ & $\mathrm{c}_{3}$ & $\mathrm{c}_{4}$ & $c_{5}$ & $\mathrm{c}_{6}$ & TJS & $\mathrm{C}_{1}$ & $\mathrm{C}_{2}$ & $\mathrm{C}_{3}$ & $\mathrm{C}_{4}$ & $\mathrm{C}_{5}$ & $\mathrm{C}_{6}$ & TJS \\
\hline $\mathrm{C}_{1}$ & 1.000 & & & & & & & 1.000 & & & & & & \\
\hline $\mathrm{C}_{2}$ & 0.829 & 1.000 & & & & & & 0.483 & 1.000 & & & & & \\
\hline $\mathrm{C}_{3}$ & 0.861 & 0.760 & 1.000 & & & & & 0.628 & 0.518 & 1.000 & & & & \\
\hline $\mathrm{C}_{4}$ & 0.825 & 0.799 & 0.783 & 1.000 & & & & 0.661 & 0.493 & 0.747 & 1.000 & & & \\
\hline $\mathrm{C}_{5}$ & 0.873 & 0.805 & 0.782 & 0.854 & 1.000 & & & 0.520 & 0.618 & 0.566 & 0.594 & 1.000 & & \\
\hline $\mathrm{C}_{6}$ & 0.792 & 0.770 & 0.641 & 0.761 & 0.873 & 1.000 & & 0.521 & 0.567 & 0.582 & 0.558 & 0.647 & 1.000 & \\
\hline
\end{tabular}

Source: own research

In order to examine the relationship between different variables, the method of covariance was used. The covariant matrix of the various satisfaction variables in the observed two periods is shown in Tab. 4.

By using the covariant matrix, the correlation coefficients of the scores of different satisfaction variables for the entire sample have been calculated.

From Tab. 5, we can see a statistically strong positive correlation between the job satisfaction variables, so that the $p$ value in the whole sample has a value of less than 0.05 , while in some we have a level of significance of 0.01 . If we analyze the correlation of satisfaction with salary $\left(\mathrm{c}_{1}\right)$ with other variables, we conclude that there is a statistically strong positive correlation with all the variables $(p<0.05)$. In 2017, the employees that are more satisfied with the salary tend to have higher level of satisfaction of cooperation with their superiors. In both monitoring periods, satisfaction with 


\begin{tabular}{|c|c|c|c|c|c|}
\hline Tab. 6: & $\begin{array}{l}\text { Regression of the im } \\
\text { in } 2017\end{array}$ & ct of inc & idual va & ables on total jc & atisfaction (TJS) \\
\hline$N=508$ & Regression equation & $\mathbf{R}$ & $\mathbf{R}^{2}$ & Standard Error & F-distribution \\
\hline 1 & 2 & 3 & 4 & 5 & 6 \\
\hline $\mathrm{C}_{1}$ & $0.458+0.848 \times \mathrm{C}_{1}$ & 0.9465 & 0.8958 & 0.324 & $4,351.04175(2)$ \\
\hline $\mathrm{C}_{2}$ & $0.087+1.023 \times \mathrm{C}_{2}$ & 0.8976 & 0.8057 & 0.442 & $2,098.50581(3)$ \\
\hline $\mathrm{C}_{3}$ & $0.743+0.767 \times \mathrm{C}_{3}$ & 0.8816 & 0.7772 & 0.474 & $1,764.76029(6)$ \\
\hline $\mathrm{C}_{4}$ & $0.542+0.908 \times \mathrm{C}_{4}$ & 0.9136 & 0.8350 & 0.408 & $2,554.59142(4)$ \\
\hline $\mathrm{C}_{5}$ & $0.705+0.791 \times \mathrm{C}_{5}$ & 0.9513 & 0.9050 & 0.309 & $4,823.44837(1)$ \\
\hline $\mathrm{C}_{6}$ & $0.698+0.732 \times \mathrm{C}_{6}$ & 0.8884 & 0.7893 & 0.462 & $1,896.02778(5)$ \\
\hline
\end{tabular}

the cooperation and relations with superiors was positively correlated with the satisfaction with the nature of the job.

The method of linear regression was used to examine the influence of independent job satisfaction variables on total job satisfaction, as shown in Tab. 6. In Tab. 6, column 2 defines the regression equation of the impact of job satisfaction on independent variables and that of average satisfaction on the total satisfaction. The coefficient of determination $\left(R^{2}\right)$ of all observed satisfaction predictors to total job satisfaction indicates that there is a positive matching in the variations. Analysis of the variance (ANOVA) determined the probability of correlation. The empirical level of the F-distribution is higher than the critical value of $\mathrm{F}$ - significance, and the regression equation can be applicable in predicting the total satisfaction trend. The T-test has analyzed the importance of the coefficient in predicting the movement of the TJS. Compared to the critical value $t$ the absolute value of t-statistics is higher, which means that the job satisfaction predictors are statistically significant in determining the total job satisfaction.

Based on the coefficient of determination $\mathrm{R}^{2}$, it can be concluded that $89.60 \%$ of the TJS change is explained by the $c_{1}$ variations. TJS increases on average by 0.848 when $\mathrm{c}_{1}$ increases by one degree. In this way the hypothesis 1 , stating that the satisfaction with salary has a statistically significant effect on total job satisfaction, has been confirmed. The result is contrary to Bassett (1994) stating that job satisfaction has not been proven to be improved by pay, as highly paid employees may still be dissatisfied if they do not like the nature of their job, but is confirmed by the findings of SousaPoza (2000) where the importance of a high income as a determinant of job satisfaction is quite high (in four of the five Eastern European countries analyzed). In Russia, for example, high income is as important as having an interesting job. Since the salary indicates how the worker is evaluated by the employer, the larger the salary is, the higher job satisfaction (Clark, 1996; 1997; Gaziougly \& Tansel, 2006; Ghinetti, 2007; Jones \& Sloane, 2009).

Based on the coefficient of determination $\mathrm{R}^{2}$, it can be concluded that $80.60 \%$ of the TJS change is explained by $c_{2}$ variations. TJS increases on average by 1.0023 when $\mathrm{C}_{2}$ increases by one degree. In this way the hypothesis 2, stating that the satisfaction with cooperation with closest associates has a statistically significant effect on total job satisfaction, has been confirmed. This is in line with the findings of (Kirmeyer \& Dougherty, 1988; Kohli, 1985; Tyagi, 1985) who concluded that positive perceptions of workplace relationships by employees may help reduce work-related stress, increase job satisfaction and motivation, and improve performance. These findings are also confirmed by Kram and Isabella (1985) maintaining that co-worker relationships are a valuable means of growth and support and Oshagbemi (2001) that individuals who had friendships with colleagues and supervisors reported higher levels of job satisfaction. In other words, in order for employees to be more satisfied with their work, it is necessary to improve cooperation with closest associates, by forming working teams and groups and promoting better interpersonal relations. This confirms the findings that relations at work, 
both with colleagues and with management, seem to be an important explanatory variable in job satisfaction equations (Clark, 1996; 1997; Sousa-Poza, 2000; Chahal et al., 2013).

Based on the coefficient of determination $\mathrm{R}^{2}$, it can be concluded that $77.71 \%$ of the TJS change is explained by the $c_{3}$ variations. TJS increases on average by 0.757 when $\mathrm{C}_{3}$ increases by one degree. In this way the hypothesis 3 stating that, the satisfaction with the possibility of promotion has a statistically significant effect on total job satisfaction, has been confirmed. This is confirmed by the results (Pergamit \& Veum, 1999; Peterson, Puia, \& Suess, 2003; Sclafane, 1999) pointing out that job satisfaction associated with opportunities for promotion and a result of individual standards for promotion depend primarily on the employee's personal and career aspirations (Cockcroft, 2001).

Based on the coefficient of determination $\mathrm{R}^{2}$, it can be concluded that $83.47 \%$ of the TJS change is explained by the $\mathrm{c}_{4}$ variations. TJS increases on average by 0.908 when $\mathrm{C}_{4}$ increases by one degree. In this way the hypothesis 4 , stating that remuneration policy has a statistically significant effect on total job satisfaction, has been confirmed. The result confirms the findings that the existence of financial reward and recognition has a significant influence on knowledge workers (Arnolds \& Boshoff, 2004). However, the system of stimulating and rewarding employees can be the result of non-transparent criteria, which sometimes also depends on personal relationships with superiors. Research conducted by Lai (2011) in small and medium enterprises, proves that the remuneration, either in the form of salary or taking other forms, is one of the factors that can increase job satisfaction. The finding that remuneration significantly effects job satisfaction has been also confirmed by Lindgren and Sanna (2008), Taylor (2013), Vosloo, Fouche and Bernard (2014) and Naji (2014). Lindgren and Sanna (2008, p. 35) concluded that respondents prefer a range of various bonuses as a complement to regular pay and surprisingly the least attractive alternative was to become a shareholder in the company. Vosloo, Fouche and Bernard (2014), and Naji (2014) have confirmed that remuneration effects job satisfaction significantly and performance appraisal technique does not contribute to job dissatisfaction (Chahal et al., 2013). In other words, the higher the remuneration given to employees, the higher the job satisfaction of employees will be. Agustiningsih et al. (2016) point out that the concept of the higher the remuneration received by employees the higher their performance will be, only occurs in normal conditions, whereas, if there are obstacles in the work implementation process, this concept does not apply. On the other hand, the results on satisfaction from remuneration show that the employees of the Polish public administration are the least satisfied with performance bonuses and this factor had the strongest positive correlation with total job satisfaction (Bialas, Litwin, \& Wasniewski, 2015, p. 130).

The highest coefficient of determination is observed in the satisfaction of respondents with the cooperation and relations with superiors $\left(c_{5}\right)$, which leads to the conclusion that $90.50 \%$ of the change in the average score of total job satisfaction is explained by $\mathrm{c}_{5}$ variations. TJS increases on average by 0.791 when the $c_{5}$ increases by one degree. In this way the hypothesis 5 , stating that the satisfaction with cooperation and good relationships with superiors has a statistically significant effect on total job satisfaction, has been confirmed. This finding is also consistent with research findings by stating that having good relations with management and an interesting job, represent two most important work-role outputs (Sousa-Poza, 2000). Overall appreciation of supervisors' leadership positively influences satisfaction with the affective aspects of their jobs as specific instructions and two-way communication in their supervisors, positively influences the satisfaction with the affective aspects of jobs (Van der Wal, SchönrockAdema, Scheele, Schripsema, Jaarsma, \& Cohen-Schotanus, 2016).

Based on the coefficient of determination $\mathrm{R}^{2}$, it can be concluded that $78.93 \%$ of the TJS change is explained by $c_{6}$ variations. TJS increases on average by 0.732 when the $\mathrm{c}_{6}$ increases by one degree. In this way the hypothesis 6 , stating that the satisfaction with nature of the job has a statistically significant effect on total job satisfaction, has been confirmed. Previous results showed that managers and professionals are more satisfied with their jobs than clerical and sales staff (Clark, 1996; Clark, 1997; Gaziouglu \& Tansel, 2006; Ghinetti, 2007). 


\section{Conclusions}

The analysis of the total job satisfaction in 2017 in the Belgrade region, compared to 2010 , reveals an increase in the level of public employees' job satisfaction. Few research initiatives have dealt with job satisfaction in the public sector in transition to a market economy, as opposed to job satisfaction in private, forprofit companies. The results can be compared with the previous research conducted in the private sector dealing with job satisfaction. Job satisfaction of public sector bank employees in India was significantly higher than the private sector bank employees but the satisfaction regarding salary, compensation, benefits and promotion were significantly higher among the private sector bank employees than the public sector bank employees (Khan \& Parveen, 2014). In Serbia, a recent research on public and private job satisfaction differential has shown that public sector workers have higher wages, work shorter working hours, and have higher levels of job satisfaction which may create a labour supply gaps for the private sector (Vladisavljević, 2017).

The statistically significant difference in the two analyzed periods (2010 and 2017) has been identified in $\mathrm{C}_{1}, \mathrm{C}_{3}, \mathrm{C}_{4}$ and $\mathrm{C}_{6}$ variables. In the last seven years, top management has mainly focused on increasing salaries, on the possibility of promotion on a hierarchical scale, on adoption of a system of remuneration and on the nature of the job.

On the other hand, employees' cooperation with their closest associates or cooperation and relations with superiors has not been improved. From this we see that top managers in the country use material incentives as motivational factors, through increased earnings, stimulating rewards and advancement on a hierarchical scale which leads to higher pay, while neglecting social components $\left(\mathrm{c}_{2}\right.$ and $\left.\mathrm{c}_{5}\right)$. Focus only on material and financial aspects, as motivational factors, may cause employee dissatisfaction in the future.

All six variables of job satisfaction added statistically significantly to the prediction. The highest coefficient of determination has been observed in the satisfaction of respondents with the cooperation and relations with superiors. On the one hand, increasing job satisfaction is important because of the human values that the enterprise respects, and on the other, because of the benefits that the employer can have through reducing absenteeism from work, reduced fluctuation, reduced rates of sick leave, a better working atmosphere and increased productivity. Organizational level should permanently improve job satisfaction through job rotation, more flexible organizational structure, long-term employment to increase loyalty, as well as by linking individual remuneration to the group performance.

The focus of interest is directed towards increasing efficiency and quality of public services. Reform of the public administration inevitably involves significant changes, and as the transition unfolds it can also bring structural changes in work organization aimed at increasing efficiency, as for example in telework (Murray Svidroňová, Mikušová Meričková, \& Nemec, 2016). Only those public enterpises that know how to value and appreciate their employees can be competitive and further on can implement a successful strategy, especially during transition period. Regular or proactive job analysis practices help to identify factors that shape the public employees' motivation and job satisfaction revealing positive relation between organizational performance and job analysis (Suthara, Chakravarthib, \& Pradhan, 2014). Promoting a more effective public sector emphasizes the responsibility of HR practices. In the future upper management needs to pay more attention to encouraging team work, developing good interpersonal relationships, strengthening cooperation between employees and superiors and promoting supportive working environment. Only in this way public employees shall be fully satisfied with his/her work, because in this way the social aspects of job satisfaction will be fulfilled.

The findings are expected to lead towards a deeper understanding of job satisfaction of public employees in transition countries and constitute useful guidelines for managers adapting to market economy management postulates. Due to the nature of the topic it proved impossible to obtain permission from a wider range of public enterprises to perform a job satisfaction survey. In addition, this study is limited to the region of Belgrade that was facing a slowdown due to economic crisis, at the time of the study, which might have affected respondents' evaluation of their satisfaction levels with the job factors. This creates an opportunity for future research to consider a broader research area, so the research findings can be widely generalized. Related 
studies need to be conducted for other kinds of public enterprises. The empirical framework developed for the study is drawn on the existant literature. The empirical testing of the model in a developing country context is a significant contribution to fill the much needed gap in the literature toward generalizing similar findings.

\section{References}

Agustiningsih, H. N., Thoyib, A., Djumilah, H., \& Noermijati, N. (2016). The effect of remuneration, job satisfaction and OCB on the employee performance. Science Journal of Business and Management, 4(6), 212-222. https://doi.org/10.11648/j.sjbm.20160406.16.

Alotaibi, A. G. (2001). Antecedents of organizational citizenship behavior: A study of public personnel in Kuwait. Public Personnel Management, 30(3), 363-376. https://doi. org/10.1177/009102600103000306.

Armstrong, M., \& Stephen, T. (2014). Armstrong's Handbook of Human Resource Management Practice (13th ed.). London: Kogan Page.

Baron, A. R. (1986). Behavior in organizations. Newton, MA: Allyn and Bacon.

Baron, A. R., \& Greenberg, J. (2003). Organizational Behaviour in organization. Understanding and managing the human side of work. Canada: Prentice Hall.

Bassett, G. (1994). The case against job satisfaction. Business Source Premier, 37(3), 61-68. https://doi.org/10.1016/00076813(94)90007-8.

Bialas, S., Litwin, J. L., \& Wasniewski, J. (2015). The Relation between Remuneration and Job Satisfaction: A case study of Public Administration employees in Pomerania Region in Polland. Social and Labour Relations, 123-133.

Brief, A. P., \& Roberson, L. (1989). Job attitude organization: An exploratory study. Journal of Applied Social Psychology, 19(9), 717-727. https://doi.org/10.1111/j.1559-1816. 1989.tb01254.x.

Buelens, M., \& Van den Broeck, H. (2007). An analysis of differences in work motivation between public and private sector organizations. Public Administration Review, 67(1), 65-74. https://doi.org/10.1111/j.15406210.2006.00697.x.

Cantarelli, P., Belardinelli, P., \& Belle, N. (2016). A meta-analysis of job satisfaction correlates in the public administration literature. Review of Public Personnel Administration, 36(2), 115-144. https://doi. org/10.1177/0734371X15578534.

Chahal, A., Chahal, S., Chowdhary, B., \& Chahal, J. (2013). Job satisfaction among bank employees: An analysis of the contributing variables towards job satisfaction. International Journal of Scientific \& Technology Research, 2(8), 11-20.

Choong, K. K. (2008). Intellectual capital: definitions, categorization and reporting models. Journal of Intellectual Capital, 9(4), 609-638. https://doi.org/10.1108/14691930810913186.

Christensen, R. (1996). Analysis of Variance, Design and Regression - Applied Statistical Methods. Champan and Hall/CRC, FL.

Christensen, R. K., \& Wright, B. E. (2011). The Effects of Public Service Motivation on Job Choice Decisions: Disentangling the Contributions of Person-Organization Fit and Person-Job Fit. Journal of Public Administration Research and Theory, 21(4), 723-743. https://doi.org/10.1093/jopart/muq085.

Clark, A. E. (1997). Job satisfaction and gender: Why are women so happy at work? Labour Economics, 4(4), 341-372. https://doi. org/10.1016/S0927-5371(97)00010-9.

Clark, A. E. (1996). Job satisfaction in Britain. British Journal of Industrial Relations, 34(2), 189-217. https://doi.org/10.1111/j.1467-8543. 1996.tb00648.x.

Cockcroft, J. (2001). Job satisfaction and organisational commitment: An empirical investigation in the Free State branches of a service organisation. Free State: University of the Free State.

Culbertson, S. (2009). Do satisfied employees mean satisfied customers? Academy of Management Perspectives, 23(1), 76-77. https://doi.org/10.5465/amp.2009.37008005.

De Menezes, L. M. (2011). Job Satisfaction and Quality Management: An Empirical Analysis. International Journal of Operations \& Production Management, 32(3), 308-328. https://doi.org/10.1108/01443571211212592.

Dess, G. G., Lumpkin, G. T., \& Eisner, A. B. (2007). Strategijski menadžment (3rd ed.). Beograd: Data Status.

Gaziouglu, S., \& Tansel, A. (2006). Job satisfaction in Britain: individual and job related factors. Applied Economics, 38(10), 1163-1171. https://doi.org/10.1080/00036840500392987.

Ghinetti, P. (2007). The public-private job satisfaction differential in Italy. Labour, 
21(2), 361-388. https://doi.org/10.1111/j.14679914.2007.00375.x.

Goris, J. R. (2006). Effect of satisfaction with communication on the relationship between individual job satisfaction congruence and job performance satisfaction. Journal of Management Development, 33(1), 64-96. https://doi.org/10.1108/02621710710777255.

Greenberg, J., \& Baron, R. A. (1998). Ponašanje ljudi u organizacijama. Beograd: Želnid.

Gregson, T. H. (1987). Factor Analysis of Multiple-Choice Format for Job Satisfaction. Psychological Reports, 61(3), 747-750. https://doi.org/10.2466/pr0.1987.61.3.747.

Gregson, T. H. (1990). Measuring job satisfaction with a multiple-choice format of the job descriptives index. Psychological Reports, 66(3), 787-793. https://doi.org/10.2466/ pr0.1990.66.3.787.

Heywood, J. S., Siebert, W. S., \& Wei, X. (2002). Worker sorting and job satisfaction: the case of union and government jobs. Industrial and Labor Relations Review, 55(4), 595-609. https://doi.org/10.2307/3270624.

Hoekstra, B. (2014). Relating training to job satisfaction: A survey of online faculty members. Journal of Adult Education, 43(1), 1-10.

Homberg, F., McCarthy, D., \& Tabvuma, V. (2015). A Meta-Analysis of the Relationship between Public Service Motivation and Job Satisfaction. Public Administration Review, 75(5), 711-722. https://doi.org/10.1111/puar.12423.

Janićijević, N. (2008). Organizaciono ponašanje. Beograd: Data Status.

John, O. P. (1990). The "Big Five" factor taxonomy: Dimensions of personality in the natural language and in questionnaires. In L. A. Pervin (Ed.), Handbook of personality theory and research (pp. 66-100). New York: Guilford.

John, O. P., \& Robins, R. W. (1993). Determinants of interjudge agreement on personality traits: The Big Five domains, observability, evaluativeness, and the unique perspective of the self. Journal of Personality, 61(4), 521-551. https://doi. org/10.1111/j.1467-6494.1993.tb00781.x.

Jones, R. J., \& Sloane, P. (2009). Regional differences in job satisfaction. Applied Economics, 41(8), 1019-1041. https://doi. org/10.1080/00036840601019067.

Judge, T., Heller, D., \& Mount, M. (2002). Five factor model of personality and job satisfaction: A meta-analysis. Journal of
Applied Psychology, 87(3), 530-541. https://doi. org/10.1037//0021-9010.87.3.530.

Khan, N. A., \& Parveen, S. (2014). A Comparative Study of Job Satisfaction of Employees in Public and Private Sector Banks in India with reference to U.P. State. Science International, 26(2), 813-820.

Kirmeyer, S. L., \& Dougherty, T. W. (1988). Workload, tension, and coping: Moderating effects of supervisor support. Personnel Psychology, 41(1), 125-139. https://doi. org/10.1111/j.1744-6570.1988.tb00635.x.

Kitchel, T., Smith, A. R., Henry, A. L., Robinson, J. S., Lawver, R. G., Park, T. D., \& Schell, A. (2012). Teacher job satisfaction and burnout viewed through social comparisons. Journal of Agricultural Education, 53(1), 31-44. https://doi.org/10.5032/jae.2012.01031.

Kohli, A. K. (1985). Some unexplored supervisory behaviors and their influence on salespeople's role clarity, specific selfesteem, job satisfaction, and motivation. Journal of Marketing Research, 22(4), 424-433. https://doi.org/10.2307/3151587.

Korunka, C., Scharitzer, D., Carayon, P., \& Sainfort, F. (2003). Employee strain and job satisfaction related to an implementation of quality in a public service organization: a longitudinal study. Work \& Stress, 17(1), 52-72. https://doi.org/10.1080/0267837031000 109526.

Kram, K. E., \& Isabella, L. A. (1985). Mentoring alternatives: The role of peer relationships in career development. Academy of Management Journal, 28(1), 110-132. https://doi.org/10.2307/256064.

Lai, H.-H. (2011). The influence of compensation system design on employee satisfaction. African Journal of Business Management, 5(26), 10718-10723. https://doi. org/10.5897/AJBM11.005.

Lindgren, L., \& Paulsson, S. (2008). An Explanatory Study of Swedish employees in The Financial sector regarding leadership style, Remuneration and elements towards Job Satisfaction. Retrieved November 25, 2017, from: http://Inu.diva-portal.org/smash/get/ diva2:205794/FULLTEXT01.pdf.

Lekić, S. (2010). Uticaj organizacionog ponašanja na organizacionu posvećenost (Doctoral dissertation). Fakultet za menadžment i poslovnu ekonomiju, Novi Pazar.

Lekić, S., \& Rajaković-Mijailović, J. (2017). Innovation as the Basis of Modern Competitive 
Companies. In Innovation, ICT and Education for the Next Generation, Thematic proceedings (pp. 236-251). Novi Sad: Faculty of Economics and Engineering Management in Novi Sad. https://doi.org/10.5937/etp1801001V.

Lekić, S., Bogetić, S., \& Vidas-Bubanja, M. (2014). Educated and satisfied worker: Foundation of modern and successful company. Journal of Engineering Management and Competitiveness (JEMC), 4(1), 27-33. https://doi.org/10.5937/jemc1401027L.

Lausev, J. (2014). What has 20 Years of Public-Private Pay Gap Literature Told Us? Eastern European Transitioning vs Developed Economies. Journal of Economic Surveys, 28(3), 516-550. https://doi.org/10.1111/joes.12039.

Lewis, G. B., \& Frank, S. A. (2002). Who Wants to Work for the Government? Public Administration Review, 62(4), 395-404. https:// doi.org/10.1111/0033-3352.00193.

Lim, L., \& Dallimore, P. (2004). Intellectual capital: Managementattitudes in service industries. Journal of Intellectual Capital, 5(1), 181-194. https://doi.org/10.1108/14691930410512996.

Locke, E. A. (1969). What is Job Satisfaction. Organizational Behavior and Human Performance, 4(4), 309-336. https://doi. org/10.1016/0030-5073(69)90013-0.

Locke, E. A. (1976). The Nature and Causes of Job Satisfaction. In M. P. Dunnette (Ed.), Handbook of Industrial and Organizational Psychology (pp. 1297-1350). Chicago, IL: Rand McNally.

Maghradi, A. (1999). Assessing the effect of job satisfaction on managers. International Journal of Value-Based Management, 12(1), 1-12. https://doi.org/10.1023/A:1007741607794.

McCrae, R. R., \& Costa, P. T. (1990). Personality in adulthood. New York: Guilford.

McCrae, R. R., \& John, O. P. (1992). An introduction to the five-factor model and its applications. Journal of Personality, 60(2), 175215. https://doi.org/10.1111/j.1467-6494.1992. tb00970.x.

Murray Svidroňová, M., Mikušová Meričková, B., \& Nemec, J. (2016). Telework in Public Sector Organizations: The Slovak National Library. International Public Administration Review, 14(2-3), 121-137. https://doi.org/10.17573/ipar.2016.2-3.06.

Naji, A. H. (2014). Components of Remuneration and Employee Satisfaction: The Impact of Effort Rewards and Career Advancement. International Journal of Arts \&
Sciences, 7(2), 425-436. https://doi.org/10.5829/ idosi.mejsr.2013.14.3.314.

Oshagbemi, T. (2001). How satisfied are academics with the behaviour/supervision of their line managers? The International Journal of Educational Management, 15(6), 283-291. https://doi.org/10.1108/EUM0000000005908.

Parnell, J. A., \& Crandall, W. (2003). Propensity for participative decision-making, job satisfaction, organizational commitment, organizational citizenship behavior, and intention to leave among Egyptian managers. Multinational Business Review, 11(1), 45-65. https://doi. org/10.1108/1525383X200300003.

Pavković, V., \& Lekić, N. (2015). Uloga strateških komunikacija u motivaciji zaposlenih u hotelskom poslovanju. Međunarodni zbornik naučnih i stručnih radova Hotelska kuća 2015. Beograd: Hores.

Pergamit, M. R., \& Veum, J. R. (1999). What is a promotion? Industrial and Labour Relations Review, 52(4), 581-601. https://doi. org/10.1177/001979399905200405.

Peterson, D. K., Puia, G. M., \& Suess, F. R. (2003). Yo Tengo La Camiseta: An exploration of job satisfaction and commitment among workers in Mexico. Journal of Leadership and Organizational Studies, 10(2), 73-88. https://doi. org/10.1177/107179190301000208.

Pržulj, Ž. (2011). Menadžment ljudskih resursa. Novi Sad: Univerzitet Educons.

Ricard, L. M., Klijn, E. H., Lewis, J. M., \& Ysa, T. (2017). Assessing Public Leadership Styles for Innovation: A Comparison of Copenhagen, Rotterdam and Barcelona. Public Management Review, 19(2), 134-156. https://doi.org/10.1080/ 14719037.2016.1148192.

Riggio, R. E. (2013). Introduction to Industrial / Organizational Psychology (6th ed.). Upper Saddle River, NJ: Pearson Prentice Hall.

Robbins, S. P., \& Judge, T. A. (2009). Organizacijsko ponašanje (12th ed.). Zagreb: Mate.

Robbins, S. P., \& Coulter, M. (2005). Menadžment. Beograd: Data Status.

Sageer, A., Rafat, N., \& Agarwal, P. (2012). Identification of Variables Affecting Employee Satisfaction and Their Impact on the Organization. Journal of Business and Management, 5(1), 32-39. https://doi.org/ 10.9790/487X-0513239.

Sclafane, S. (1999). MGA Managers in Sync with Employees on Job Satisfaction Issues, Survey Finds. National Underwriter, 103(22), 4-24. 
Skaalvik, E. M., \& Skaalvik, S. (2015). Job satisfaction, stress and coping strategies in the teaching profession: What do teachers say? International Education Studies, 8(3), 181-192. https://doi.org/10.5539/ies.v8n3p181.

Smith, P. C., Kendall, M., \& Hum, C. L. (1969). The meaurement of satisfaction in work and retirement. Chicago, IL: Rand McNally.

Sousa-Poza, A., \& Sousa-Poza, A. A. (2000). Well-being at work: a cross national analysis of the levels and determinants of job satisfaction. Journal of Socio-Economics, 29(6), 517-538. https://doi.org/10.1016/S10535357(00)00085-8.

Staroňová, K. (2017). Performance Appraisal in the EU Member States and the European Commission. Survey commissioned by the Slovak EU-Presidency. Bratislava: Government Office.

Suthara, B., Chakravarthib, T. L., \& Pradhan, S. (2014). Impacts of Job Analysis on Organizational Performance: An Inquiry on Indian Public Sector Enterprises. Procedia Economics and Finance, 11, 166-181. https://doi.org/10.1016/S2212-5671(14)00186-5.

Tahir, S., Yusoff, R. B., Azam, K., Khan, A., \& Kaleem, S. (2012). The Effects of Work Overload on the Employees' Performance in relation to Customer Satisfaction: A Case of Water \& Power Development Authority, Attock, Pakistan. World Journal of Social Sciences, 2(1), 174-181.

Taylor, J. (2013). Remuneration Policy in the Australian Public Service: Fairness and Trust. Australian Political Studies Association Annual Conference, 30 September - 2 October 2013. Perth: Murdoch University.

Tschirhart, M., Reed, K. K., Freeman, S. J., \& Anker, A. L. (2008). Is the Grass Greener? Sector Shifting and Choice of Sector by MPA and MBA Graduates. Nonprofit and Voluntary Sector Quarterly, 37(4), 668-688. https://doi. org/10.1177/0899764008314808.

Tyagi, P. K. (1985). Relative importance of key job dimensions and leadership behaviors in motivating salesperson work performance. Journal of Marketing, 49(3), 76-86. https://doi. org/10.2307/1251617.
Van der Wal, M. A., Schönrock-Adema, J., Scheele, F., Schripsema, N. R., Jaarsma, A. D. C., \& Cohen-Schotanus, J. (2016). Supervisor leadership in relation to resident job satisfaction. BMC Medical Education, 16(194). https://doi. org/10.1186/s12909-016-0688-z.

Vladisavljević, M. (2017). Public private job satisfaction differential in Serbia: evidence from SILC data. In Education for entrepreneurial business and employment (pp. 186-206). Newton Abbot: Compass Publishing.

Vosloo, W., Fouche, J., \& Barnard, J. (2014). The Relationship Between Financial Efficacy, Satisfaction With Remuneration And Personal Financial Well-Being. International Business \& Economics Research Journal, 13(6), 14551470. https://doi.org/10.19030/iber.v13i6.8934.

Yousef, D. A. (2017). Organizational commitment, job satisfaction and attitudes toward organizational change: A study in the local government. International Journal of Public Administration, 40(1), 77-88. https://doi. org/10.1080/01900692.2015.1072217.

Nemanja Lekić, PhD student

Belgrade Business School - Higher Education Institution for Applied Studies

Serbia nemanja.lekic@bbs.edu.rs

Jelena Vapa-Tankosić, Ph.D. University Business Academy in Novi Sad Faculty of Economics and Engineering Management Serbia jvapa@fimek.edu.rs

Jasmina Rajaković-Mijailović, Ph.D. University Business Academy in Novi Sad Faculty of Law for Commerce and Judiciary in Novi Sad

Serbia jasminarajakovic@yahoo.com

Snežana Lekić, Ph.D

Belgrade Business School - Higher Education Institution for Applied Studies Serbia snezana.lekic@bbs.edu.rs 


\title{
AN ANALYSIS OF FACTORS INFLUENCING EMPLOYEE JOB SATISFACTION IN A PUBLIC SECTOR
}

\author{
Nemanja Lekić, Jelena Vapa-Tankosić, Jasmina Rajaković-Mijailović, \\ Snežana Lekić
}

Public enterprises can only be successful when they base their business strategy and their organizational processes on the satisfaction of their employees. The subject of this research is an analysis of job satisfaction in public sector in Belgrade region in two independent time periods (in 2017 and 2010). The aim of the research was to analyse whether the salary, cooperation with closest associates, and possibility of promotion, remuneration policy, cooperation and good relationships with superiors and nature of the job are directly and positively associated with total job satisfaction. The recent study in 2017 was carried out on 508 public employees on lower positions of leading public sector enterpises. The data was analysed by correlation and regression analysis in the statistical software package SPSS. In the last seven years, the increase in job satisfaction in regard to satisfaction with salaries, the promotion on a hierarchical scale, remuneration policy and the nature of the job, has been observed. On the other hand, the results show that the employees' satisfaction with cooperation with their closest associates or cooperation and relations with superiors has not been improved. Considering the results of the data, the researchers are able to draw a conclusion which is also consistent with the prevous research, that the analysed factors have a direct and positive influence on the job satisfaction. The conclusions point out that employee job satisfaction analysis can be a powerful tool to enhance organizational performance as well as guidance for the knowledgeable allocation of resources. This study contributes to the analysis of job satisfaction in public sector, which has not been investigated enough, as opposed to job satisfaction in private, for-profit corporations.

Key Words: Job satisfaction, organizational performance, public enterprises, transition.

JEL Classification: C10, J28, L32.

DOI: 10.15240/tul/001/2019-3-006 